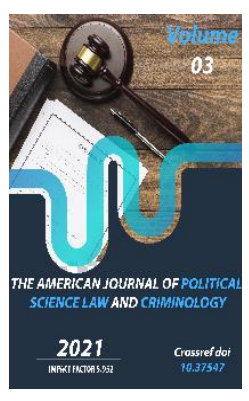

\title{
Signs Of The Subjective Side Torture Of The Individual
}

\author{
Zafarjon Omonov \\ Researcher Of The Academy Of MIA Of The Republic Of Uzbekistan
}

Copyright: Original content from this work may be used under the terms of the creative commons attributes 4.0 licence.

\section{ABSTRACT}

The article discusses the required and necessary elements of a crime, subjective symptoms mentioned in criminal legal norms, independent elements of torture, to be separate study, highlights the subjective aspect of torture, the behavior of persons, including illegal, its external (physical) and internal (mental) side, the processes in the psyche of the perpetrator, the act or omission, committed socially dangerous acts intentionally or negligently, the circumstances of guilt as mental attitudes, analyzes the circumstances of mental attitude as consisting of 1) smart time 2) the date of the will, 3) emotional, the differentiation of the two forms of guilt - deliberate and careless, differentiation of types of retaliation in volitional element, optional (proper retribution) or conscious conceded (twisted retribution), the motives and goals of torture, personal animosity.

\section{KEYWORDS}

The subjective side of torture, torture, subjective signs, personal behavior, illegal behavior, action, inaction, intentional, careless, volitional behavior, intellectual moment, moment of will, emotional moment, direct intent, curve motives and goals of intentional torture.

\section{INTRODUCTION}

Part two of article 16 of the Criminal Code of the Republic of Uzbekistan of 1994 for the first time in principle defined the grounds for bringing to justice, that is, the basis for bringing 
to justice is the commission of an act that has all the signs of a crime provided for by the Criminal Code. In turn, in order to qualify the committed socially dangerous act as a crime, it is necessary to establish not only the presence of an objective or objective side of the composition of this crime, but also to determine its subjective signs specified in the criminal law norms. Based on a comprehensive and multi-faceted analysis of torture, it is necessary to analyze the subject and the subjective side of this crime.

The next of the independent elements of torture to be studied is the subjective side of this crime.

The subjective side of the corpus delicti is understood as the mental attitude of a person who has committed a socially dangerous act, defined by the criminal law as a crime, to his act and its consequences [1].

Personal behavior, including illegal behavior, embodies the external (physical) and internal (psychological) sides. As A. I. Rarog notes, crimes are characterized not only by external signs, but also by signs inherent in their internal side. Namely, the clarification of the subjective side of the crime creates difficulties in law enforcement practice as a result of complex mental processes [2].

In the theory of criminal law, the components of criminal behavior that directly manifest the internal mental activity of a person associated with the commission of a crime are studied from the subjective side of the corpus delicti. In contrast to the objective side, the subjective side studies the processes in the psyche of the guilty. It is determined by analyzing and evaluating the behavior of the offender, the conditions for committing the crime [3].
The subjective side of the composition of the crime of torture is a set of essential features that characterize the mental attitude of a person to the crime being committed at the time of committing the crime provided for in Article 110 of the Criminal Code of the Republic of Uzbekistan.

The subjective side of the crime consists of such features as guilt, motive and purpose. At the same time, guilt is a necessary sign of the subjective side of the crime, and the motive and purpose are optional signs [4].

However, with regard to this approach, A. I. Rarog approached the subjective side of the crime from a critical point of view. He refers to the mental state of the individual as one of the signs of the subjective side of the crime [5].

This approach to the legal nature of the mental state, in our opinion, is justified, since the mental state can not act as a characteristic of the mental progress associated with the crime committed.

Guilt is an essential feature of the subjective side of any crime. Guilt in the form of intent or negligence is a subjective condition of criminal liability. Therefore, in each specific case, when the question of criminal liability is raised, the mental attitude of a person to the socially dangerous act committed by him and the consequences that occurred on its basis should be determined, and in cases where the article of the Criminal Code does not specify the origin of the consequences (including Article 110 of the Criminal Code), to the action or inaction itself [6].

In accordance with article 20 of the Criminal Code of the Republic of Uzbekistan, a person who intentionally or negligently committed a socially dangerous act provided for by the 
Criminal Code may be found guilty of committing a crime. This article of the Criminal Code and other norms contained in this chapter emphasize the importance of "guilt» as an element of the subjective side of the composition of the crime under investigation.

H. R. Ochilov notes that the circumstances of guilt as a mental relationship are mental and volitional, which together form guilt, while 1) the mental state is when a person expresses that he is aware of the nature of a socially dangerous act committed by him; 2) the volitional state - assumes the ability of an individual to control his actions [7]. Supporters of this classification are also V. N. Kudryavtsev,

\section{A.V. Naumov [8].}

However, P. Bakunov argues that guilt as a mental attitude consists of 1) an intellectual moment, 2) a moment of will, 3) an emotional moment. At the same time, in contrast to the above points, it is recognized that all human activity should include not only volitional, but also cognitive and emotional processes, because without them, as shown in the psychological literature, neither goal setting nor the implementation of the activity itself is possible [9].

In accordance with the current criminal law, there are two forms of guilt - intentional and negligent (Article 20 of the Criminal Code). The division of guilt into forms is of great legal importance. Because it is the form of guilt that determines the qualification of crimes, the individualization of criminal responsibility and punishment, etc. It is for these reasons that it is important to determine the form of guilt in the crime provided for in Article 110 of the Criminal Code of the Republic of Uzbekistan.
In accordance with the first part of article 21 of the Criminal Code of the Republic of Uzbekistan, the time of committing a crime in the article of the Criminal Code is considered the time of committing a socially dangerous act, which is recognized as committed intentionally, if the person who committed it realized the socially dangerous nature of his act and wanted to commit such a crime.

This rule also applies to torture. Despite the fact that the wording of the first part of Article 110 of the Criminal Code does not contain a form of guilt in the commission of torture, based on the fact that the main sign of the use of physical violence is the intentional commission of this violence, the fact of intentional commission of torture does not raise any doubts.

In accordance with the second part of Article 21 of the Criminal Code of the Republic of Uzbekistan, acts recognized in the article of the Criminal Code as completed at the time of the onset of socially dangerous consequences can be committed with direct or indirect intent.

Part three of article 21 of the current criminal law establishes that such a crime can be recognized as committed intentionally if the person was aware of the socially dangerous nature of his act, its socially dangerous consequences and wanted them to occur.

Such crimes are recognized as committed intentionally if the person was aware of the socially dangerous nature of his act, its socially dangerous consequences and allowed them to occur.

According to the current criminal legislation, both types of intent are common to the mental state - the ability of a person to realize the public danger of their actions. The types of 
intent differ according to the volitional element-desire (direct intent) or conscious permission (indirect intent) [10].

The intellectual moment of direct intent is manifested, first of all, in the awareness of the public danger of the act committed by the guilty person. In addition, the intellectual moment of direct intent is expressed in the individual's ability to see the real occurrence or possibility of the occurrence of a socially dangerous consequence.

In turn, the volitional state of direct intent manifests itself in the desire of the guilty person for the occurrence of visible consequences [11].

Based on the above, we have considered that from the subjective side of the torture is a deliberate crime, and the motive and purpose of the commission do not matter in the qualification of the crime. However, in the legal literature, opinions about the form of guilt through which the crime of torture is committed are divided.

While a number of authors claim that torture can only be committed with direct intent [12], others do not deny that torture can also be committed with indirect intent [13].

In our opinion, since, as we noted above, torture is a crime of formal composition, and in crimes of formal composition, the person realized the socially dangerous nature of his act and wanted to commit such an act, then by virtue of the recognition of the crime committed with direct intent, torture is committed only with direct intent.

When committing torture with direct intent, the perpetrator is aware of the social danger of torture by systematic beatings or other actions, and also foresees the occurrence or possibility of torture in the form of physical or mental suffering and wants it.

The motives and goals of committing torture can be different - personal hostility, revenge, jealousy, hatred, etc. However, they do not act as signs that form the corpus delicti specified in part one of Article 110 of the Criminal Code of the Republic of Uzbekistan.

At the same time, certain motives and goals are recognized in the legislation as qualifying signs of the crime of torture. These are tortures committed, as specified in part two of article 110 of the Criminal Code of the Republic of Uzbekistan, a) against a minor; b) a woman who was known to the perpetrator to be in a state of pregnancy; c) a person who was known to the perpetrator to be in a helpless state.

P. N. Kabanov, in contrast to the above points, proposed to attribute the presence of physical and mental suffering to the number of necessary signs of the crime of torture [14]. In his opinion, such an amendment to the criminal law will facilitate the differentiation of torture from intentional infliction of light bodily harm and other violent crimes.

Concluding the study of the subjective signs of the crime of torture, we can draw the following conclusions:

1. The subject of torture may be a physical sane person who has reached the age of sixteen at the time of the commission of the crime. Based on the complex form of the crime of torture, it should be taken into account that at the time of the commission of torture with systematic beatings or other actions from the facts forming 
complicity, the person must be sixteen years old.

2. On the subjective side, torture is committed through a deliberate form of guilt. When qualifying the crime specified in article 110 of the Criminal Code of the Republic of Uzbekistan, since torture is a formal crime, it is committed only with direct intent, there is no indirect intent.

3. The motive and purpose of the commission of the crime are not among the main signs of the composition of the torture. The separate motives and goals specified in the second part of Article 110 of the Criminal Code of the Republic of Uzbekistan determine the qualifying signs of the crime of torture committed a) against a minor; $b$ ) a woman who was known to the perpetrator to be in a state of pregnancy; c) a person who was known to the perpetrator to be in a violent state.

\section{REFERENCES}

1. Ўзбекистон юридик энциклопедияси. / Муаллифлар жамоаси. - Тошкент: Адолат, 2010. - Б. 185.; Батафсилроқ қаранг: Рустамбаев M.Х. Комментарий к Уголовному кодексу Республики Узбекистан. Общая часть / Под общ.ред. А.А.Палван-Заде. Тошкент: Ўқитувчи, 2004. - С. 164-191.; Жиноят хуқуқи. Умумий қисм: Дарслик / Муаллифлар жамоаси. Тошкент: Ўзбекистон Республикаси ИИВ Академияси, 2004. - Б. 161.; Очилов Х.Р. Саволлар ва жавоблар (умумий қисм). Ўқув қўлланма. Тошкент: Янги аср авлоди, 2009. - Б. 33.
2. Рарог А. И. Квалификация преступлений по субъективным признакам. - СПб., 2003. - С. 10.;Российское уголовное право. В двух томах. Том 1. Общая часть. / Под ред. А. И. Рарога. - М., 2003. - С. 157.

3. Уголовное право России. Части Общая и особенная: учебник, - 5-е изд. / Под ред. М. П. Журавлев, А. В. Наумов. - М., 2004. -С. 87.

4. Рустамбаев М.Х. Комментарий к Уголовному кодексу Республики Узбекистан. Общая часть / Под общ.ред. А.А.Палван-Заде. Тошкент: Ўқитувчи, 2004. - С. 174.; Жиноят хуқуқи. Умумий қисм: Дарслик / Муаллифлар жамоаси. Тошкент: Ўзбекистон Республикаси ИИВ Академияси, 2004. - Б. 161-163.; Очилов Х.Р. Саволлар ва жавоблар (умумий қисм). Ўқув қўлланма. Тошкент: Янги аср авлоди, 2009. - Б. 33.

5. Рарог А. И. Квалификация преступлений по субъективным признакам. - СПб., 2003. -С. 59-61.

6. Жиноят хуқуқи. Умумий қисм: Дарслик / Муаллифлар жамоаси. Тошкент: Ўзбекистон Республикаси ИИВ Академияси, 2004. - Б. 162.

7. Очилов Х.Р. Саволлар ва жавоблар (умумий қисм). Ўқув қўлланма. Тошкент: Янги аср авлоди, 2009. - Б. 34.

8. Курс российского уголовного права. Общая часть. / Под ред. В. Н. Кудрявцева, А. В. Наумова. - М., 2001. - С. 268.

9. Бакунов П. Айб жиноят субъектив томонининг зарурий белгиси 
сифатида. - Тошкент: Адолат, 2006. Б. 47-53.

10. Бакунов П. Айб жиноят субъектив томонининг зарурий белгиси сифатида. - Тошкент: Адолат, 2006. Б. 56-57.

11. Шарапов Р. Д. Физическое насилие в уголовном праве / Р. Д. Шарапов. СПб.: Юридический центр Пресс, 2001. - С. 230 - 231;;Землюков С. В. Уголловно-правовые проблемы преступного вреда. - Новосилбирск, 1991.-С. 126.;Уголовное право России. Части Общая и особенная: учебник. 5-е изд. - М., 2004. - С. 88 -89.

12. Рустамбаев М.Х. Жиноят хуқуқи: Махсус қисм. - Тошкент, Ўқитувчи, 2003. - Б. 87.; Зубкова В. И. Ответственность за преступления против личности по законодательству России. - М.: Норма, 2005. - С. 143.; Комменталрий к Уголовному кодексу Российской Федерации. / Отв. ред. А.И. Рарог. М.: Проспект, 2004. - С. 187.; Вениаминов В. Г. Уголовная ответственность за побои и истязание: дис. ... канд. юрид. наук. Саралтов, 2005.-С. 119-120.

13. Уголовное право. Особенная часть: учебник. / Под ред. Л.Д. Гаухмана, С.В. Максимова. - М.: ЭКСМО, 2004. С. 69.; Кабанов П.Н. Уголовная отлветственность за побои и истязание: автореф. дис. ... канд. юрид. наук. - М., 2006. - С. 8.

14. Кабанов П.Н. Уголовная ответственность за побои и истязание: автореф. дис. ... канд. юрид. наук. - М., 2006. - С. 8-9. 